\title{
REVOLUÇÕES DE INDEPENDÊNCIA NA AMÉRICA HISPÂNICA: UMA REFLEXÃO HISTORIOGRÁFICA
}

\author{
Maria Elisa Noronha de Sá Mäder \\ Pontifícia Universidade Católica do Rio de Janeiro (PUC-RJ)
}

\section{Resumo}

$\mathrm{O}$ artigo discute como a historiografia tem interpretado os movimentos de independência na América Hispânica, atribuindo-lhes ou não um caráter revolucionário. O objetivo é fazer um balanço das diversas abordagens historiográficas acerca do tema, destacando principalmente os diferentes conceitos de revolução e os múltiplos significados a partir dos quais estas são conformadas.

\section{Palavras-chaves}

Revolução • independências • América Hispânica.

\section{Abstract}

The article discusses how historiography has interpreted independence movements in Hispanic America attributing to them a revolutionary character. The objective is to look over the diverse historiographic approaches of this theme, focusing on the different concepts of revolution and its multiple meanings from which they are derived.

\section{Keywords}

Revolution • independence • Hispanic America 
"Desde que a traiçoeira conduta do Imperador da França arrancou da Espanha o mais amado de seus monarcas, o reino ficou acéfalo, e dissipado o princípio no qual unicamente podiam concentrar-se os verdadeiros direitos da soberania. [...] Fernando VII tinha um reino, mas não podia governá-lo; a monarquia espanhola tinha um rei, mas não podia ser governada por ele; $e$ neste conflito a nação devia recorrer a si mesma para governar-se, defenderse, salvar-se e recuperar seu monarca ${ }^{l}$ ". Com estas palavras Mariano Moreno, político e jurista atuante no movimento de independência da região do Prata, manifestava sua opinião sobre os eventos vividos àquela época. Estávamos no ano de 1810, o chamado ano revolucionário, e ele falava da conjuntura iniciada com a invasão napoleônica da Península Ibérica em 1807. Apesar das inúmeras diferenças, este acontecimento provocou mudanças definitivas no mundo colonial ibérico. Seja em Portugal, onde a invasão napoleônica ocasionou a transferência da família real para o Brasil, seja na Espanha, onde ocorreu a chamada "acefalia do reino", com a deposição do rei Fernando VII, as colônias ibéricas viveram a partir daí uma fase de intensa experimentação política, na qual se construíram novos conceitos, palavras e projetos na tentativa de dar sentido às situações então vivenciadas.

Neste ano de 1810, surpreendentemente, os movimentos de independência se manifestaram na América Hispânica com enorme velocidade e assombrosa simultaneidade, do México, no vice-reino da Nova Espanha, a Buenos Aires, no vice-reino do Rio da Prata. Apesar das dificuldades de comunicação e das imensas distâncias físicas, esta sincronização revelava não só ecos dos acontecimentos externos, mas também o surgimento no interior da elite colonial de diversos, e muitas vezes contraditórios, posicionamentos e projetos políticos que visavam responder aos desafios impostos por este contexto político.

Em 1810, 18 milhões de habitantes viviam nas Américas sob o governo da Espanha. Destes, oito milhões eram indígenas originários do Novo Mundo; um milhão eram negros trazidos da África; cinco milhões eram mestiços; e a minoria de quatro milhões era de brancos, tanto espanhóis peninsulares, os chamados chapetones, como crioulos, isto é, brancos nascidos nas Américas. Estes últimos viviam uma contraditória situação: estavam no topo da sociedade

\footnotetext{
${ }^{1}$ MORENO, Mariano. Manifesto de la Junta. Gazeta de Buenos Aires, $n^{\circ} 19$. Jueves 11 de octubre de 1810. In: Representación de los hacendados y otros escritos. $1^{\text {a }}$ Ed., Buenos Aires: Emecé, 1998, p. 159-159.
} 
colonial, mas, no entanto, desempenhavam um papel secundário ante os espanhóis peninsulares em termos de privilégios, acesso à riqueza, aos monopólios, à administração e às decisões políticas. Além disso, sentiam-se ameaçados pelas maiorias não-crioulas de índios, negros e mestiços.

Durante a segunda metade do século XVIII e as primeiras décadas do século XIX, o mundo espanhol sofreu uma grande transformação. Os reinados de Carlos III e Carlos IV (1759-1808) testemunharam o desenvolvimento de um pensamento político moderno ilustrado - que enfatizava a liberdade, igualdade, direitos civis, o governo das leis, a representação constitucional e o laissez-faire econômico - entre um pequeno, porém significativo, número de espanhóispeninsulares e espanhóis-americanos. Baseadas nestas idéias as reformas bourbônicas, impostas pela metrópole espanhola às suas colônias americanas com os objetivos de aumentar a prosperidade econômica da Espanha e manter a sua hegemonia política, aumentaram o descontentamento de grande parte da elite colonial crioula. Ao enquadrar o mundo hispano-americano dentro de seus interesses, a Coroa ameaçava os múltiplos interesses locais desenvolvidos durante os três séculos de colonização, seus sentimentos de autonomia e de identidade.

O colapso da monarquia espanhola, em 1808, deixou essa minoria liberal em condições, sem precedentes, para implantar alguns destes objetivos. A abdicação forçada do rei da Espanha, unanimemente rejeitada pelos americanos e peninsulares abriu caminho para que estes assumissem os poderes detidos pelo rei e começassem a debater sobre o fundamento e o conceito de soberania, sobre a representação, a idéia de nação, e a necessidade de dar uma nova constituição à monarquia. Estes homens começavam a compartilhar sentimentos e a constituir um novo vocabulário político, capazes de fazer nascer uma modernidade política, tanto em termos de idéias como de ações que configurariam uma nova prática política no interior das sociedades coloniais. Uma verdadeira revolução que o tradicionalismo da monarquia espanhola não conseguiu pressentir tão próxima.

É a partir dessas afirmativas iniciais que proponho analisar como a historiografia tem pensado o caráter revolucionário dos movimentos de independência na América Hispânica. Na última década do século passado, diversos estudiosos retomaram o interesse pelo estudo dos processos de independência, elaborando novas abordagens que tratavam de temas como as origens ideológicas desses movimentos, seu caráter continuísta ou de ruptura com o período anterior, o papel da Constituição espanhola de Cádiz como inspiradora dos processos constitucionais americanos, o questionamento da figura dos caudilhos, entre 
outros. Estudos como os de José Carlos Chiaramonte, Túlio Halperín Donghi, John Lynch, Manuel Chust, Jaime Rodríguez, François-Xavier Guerra, Antonio $\mathrm{Annino}^{2}$, destacam-se nesta retomada do tema das independências, a partir de diferentes perspectivas e/ou diversas áreas geográficas. Trabalharei aqui mais de perto com o conceito de revolução e a análise empreendida por FrançoisXavier Guerra nos anos 1990, a partir da publicação de seu livro Modernidad y Independencias: ensayos sobre las revoluciones hispanicas ${ }^{3}$. Acredito que seu trabalho foi fundamental para trazer de volta o tema da revolução às discussões historiográficas sobre as independências na América Hispânica.

Para François-Xavier Guerra tanto a Revolução Liberal espanhola quanto as independências hispano-americanas foram um processo único que começou com o surgimento da modernidade em uma monarquia do Antigo Regime e vai desembocar na desintegração desse conjunto político em múltiplos estados soberanos. Quanto à natureza desse processo, tanto para seus protagonistas - sejam os espanhóis americanos ou os espanhóis peninsulares - quanto para uma antiga tradição historiográfica, trata-se, sem dúvida, de um processo revolucionário. A questão é que o consenso terminológico sobre o caráter revolucionário desses fenômenos escamoteia diferenças consideráveis que dependem dos diversos significados dados ao conceito de revolução. Assim, por exemplo, o caráter revolucionário daqueles acontecimentos vividos como certeza pelos seus protagonistas, tendeu a ser minimizado e tornou-se bastante problemático à luz de uma concepção de revolução entendida como uma radical transformação das estruturas sociais e econômicas, ou como o meio de chegada ao poder de uma nova classe social. Como deste ponto de vista as independências na América Hispânica trouxeram consigo poucas transformações substanciais nas estruturas

\footnotetext{
${ }^{2}$ ANNINO, A; LEIVA, L. C.; GUERRA, F. X. (coord.) De los Imperios a las Naciones: Iberoamérica. Zaragoza/Espanha: Ibercaja, 1994; CHIARAMONTE, José Carlos. Ciudades, provincias, Estados: Orígenes da la Nación Argentina (1800 - 1846). Buenos Aires: Compañia Editora Espasa Calpe, 1997; CHUST, Manuel. La cuestión nacional americana en las Cortes de Cádiz. Valencia: Universidad Nacional de Educación a Distancia / Centro Francisco Tomás y Valiente/ UNAM-IIH, 1999; GUERRA, François-Xavier. Modernidad y Independencias: ensayos sobre las revoluciones hispánicas. México: Editorial Mapfre; Fondo de Cultura Económica, 1992; HALPERIN DONGHI, Túlio. Reforma y disolución de los impérios ibéricos, 1750-1850. Madrid: Alianza, 1985; LYNCH, John. Las Revoluciones Hispanoamericanas, 1808-1826. Barcelona: Ariel, 1989; RODRÍGUEZ O., Jaime E. La independencia de la América Española. México: Fondo de Cultura Económica, 1994.

${ }^{3}$ GUERRA, François-Xavier. Modernidad y Independencias: ensayos sobre las revoluciones hispánicas. México: Editorial Mapfre; Fondo de Cultura Económica, 1992.
} 
econômicas ou sociais, a tendência de certa historiografia foi atenuar ou até negar seu caráter revolucionário. Assim, as revoluções de independência passaram a ser consideradas por muitos autores como um fenômeno de caráter puramente político - aqui entendido como a ruptura dos vínculos coloniais com a metrópole e também como a mera substituição no poder político dos peninsulares pelos crioulos -, e, portanto, de importância secundária no que diz respeito às permanências estruturais.

O mesmo ocorreu com relação à análise sobre o caráter revolucionário do processo iniciado em 1808 na Espanha. Apesar de constantemente reconhecido, este aparece sempre acrescido do adjetivo "liberal", com a intenção de qualificálo como uma revolução limitada, diminuindo a força da palavra revolução. $\mathrm{O}$ fato é que em ambos os casos, utilizando-se de critérios surgidos das interpretações clássicas da Revolução Francesa, elas são tratadas quase sempre como revoluções burguesas, realizadas na Espanha por uma burguesia revolucionária, e na América Hispânica por uma burguesia crioula.

Para François-Xavier Guerra esse tipo de interpretação não se sustenta mais, na medida em que "reduzir estas revoluções a uma série de mudanças institucionais, sociais ou econômicas, deixa de lado o traço mais evidente daquela época: a consciência que têm os atores, e que todas as fontes refletem, de abordar uma nova era, de estar fundando um homem novo, uma nova sociedade e uma nova política". Importante observar os novos conteúdos semânticos imputados a estes termos: o homem novo é agora concebido como um indivíduo, livre dos vínculos da sociedade estamental e corporativa; a nova sociedade é uma sociedade contratual originada de um novo pacto social; e a novidade na política é a idéia da soberania encarnada no povo. A força e a amplitude com que estas transformações se impõem, criando profundas e irreversíveis rupturas, são observadas pelos próprios atores e aparecem englobadas por François-Xavier Guerra no conceito de modernidade.

$\mathrm{O}$ autor também questiona o problema de se afirmar que este novo sistema de referências tenha sido elaborado e imposto por um grupo social determinado e que este seja chamado de burguês. Entre os principais atores do processo revolucionário estão alguns burgueses, mas sua maioria é composta por clérigos, professores e estudantes, empregados públicos, profissionais liberais, nobres,

${ }^{4}$ Idem, p. 13. 
etc., homens cuja característica comum não é uma mesma situação socioeconômica, mas seu pertencimento a um mesmo mundo cultural.

O importante a ressaltar é que apesar do termo revolução até então aparecer com freqüência na historiografia associado aos movimentos de independência hispano-americanos ${ }^{5}$, este parecia sempre indicar uma ausência, sendo construído a partir de uma concepção de história marcada pelo continuísmo e pelo conservadorismo. Partia-se de uma historiografia marcadamente nacionalista e liberal, que desde o século XIX utiliza o termo revolução como sinônimo de guerras de independência, ressaltando apenas a ruptura do vínculo colonial existente entre a metrópole e suas colônias. O conceito de revolução é utilizado aí de maneira pouco elaborada ou problematizado. Além disso, essa historiografia é marcada por uma postura anacrônica e teleológica, que pressupõe a existência de um nacionalismo que teria precedido o processo de construção dos estados nacionais, levando à crença de que a maioria das nações americanas já existia desde o momento da independência. Busca-se assim reconhecer nos movimentos de independência a origem dos estados nacionais que se formarão posteriormente ao longo do século XIX.

Manuel Chust e José A. Serrano, no livro que organizaram sobre as independências ibero-americanas ${ }^{6}$, referem-se ao predomínio desta historiografia liberal e nacionalista como um "consenso historiográfico" que vigorou até finais dos anos 1950 em grande parte do meio acadêmico ibero-americano. As historiografias das diversas repúblicas coincidiam no forte nacionalismo que impregnava todas as análises das guerras de independência da região. Para a maioria destes historiadores tratava-se de uma luta entre realistas e insurgentes, entre gachupines e patriotas, constituindo interpretações maniqueístas da independência, entre bons e maus, entre patriotas e traidores, posicionados a partir de sua adesão ou não à causa nacional. Construiu-se assim um discurso que se tornou hegemônico e que teve o sentido de unificar a história das sociedades ibero-americanas profundamente diversificadas étnica e socioeconomicamente,

\footnotetext{
${ }^{5}$ Seja por uma historiografia nacionalista e liberal que predominou nas escritas sobre as independências até meados dos anos 50 do século passado, seja por uma historiografia de viés marxista predominante nos anos 1960/70, que negava o caráter revolucionário destes movimentos, como veremos ao longo do texto. Para exemplos de historiadores e trabalhos representativos destas vertentes historiográficas ver os artigos e a bibliografia indicada em CHUST, Manuel y SERRANO, José Antonio (Eds.). Debates sobre las independencias iberoamericanas. Madrid; Frankfurt: AHILA/Iberoamericana/Vervuert, 2007.

${ }^{6}$ CHUST, Manuel y SERRANO, José Antonio (Eds.), op. cit.
} 
e com grandes contrastes regionais. As guerras de independência interpretadas assim à luz do nacionalismo se converteram em substrato histórico comum das nações ibero-americanas, produzindo uma importante síntese étnica, cultural, social e territorial.

Desta leitura adveio também uma concepção de povo como um ente homogêneo e sem fissuras, ou melhor, com algumas pequenas fissuras como a dos realistas ou "não nacionais", identificados aos espanhóis peninsulares em geral e a alguns grupos indígenas que se opuseram à "independência nacional”, em contraposição ao "povo" que defendeu a independência da nação "oprimida por mais de trezentos anos de colonização”. No caso dos espanhóis peninsulares - burocratas, eclesiásticos, militares, comerciantes monopolistas, etc. -, os vínculos de nascimento teriam prevalecido sobre os vínculos políticos ou econômicos. Quanto aos indígenas, a maior parte de suas comunidades permaneceu alijada dos processos de independência porque se tratava de uma guerra entre crioulos e peninsulares, e também pela sua alienação, fruto de séculos de colonialismo e dominação. Esta concepção de povo contribuiu fortemente para o entendimento também pouco problematizado do caráter revolucionário dos movimentos de independência.

A idéia de revolução entendida como uma ruptura radical aparecia, no entanto, sempre relacionada ao processo de independência das treze colônias inglesas, a chamada Revolução Americana, e também, com mais desconforto pelo seu elemento mais radical, ao caso da independência do Haiti em 1804. Se na América Hispânica nada havia mudado, na América anglo-saxônica a ruptura havia ampliado a noção de cidadania e um inédito sistema político nacional, republicano e democrático havia sido instaurado naquele mundo. Além disso, a unidade territorial havia sido preservada, garantindo a estabilidade e a coesão daquele estado nacional. O processo de independência da Hispano-América era apresentado como o oposto a tudo isso. Contrariamente ele dera origem a repúblicas marcadas pela instabilidade, pelo fracionamento, pelo caudilhismo e pela desordem. Assim, por comparação, a noção de revolução como novidade ou ruptura era descartada, à medida que o grupo social que havia liderado a construção dos estados nacionais hispano-americanos era a elite crioula, grupo hegemônico desde os tempos coloniais.

Outra tendência historiográfica que merece destaque pela sua força e longevidade é a que apresentou a idéia de revolução apenas como a expressão de uma causalidade externa. Nessas interpretações as independências têm seu 
caráter revolucionário reconhecido pelo fato de terem sido parte integrante de um processo maior e inevitável de revoluções burguesas que afetaram todo o mundo Atlântico naquele período. Tendência forte nos anos 1950, período da Guerra Fria, quando o mundo capitalista liderado pelos Estados Unidos esforçava-se para conter os avanços do bloco socialista no contexto do pós $2^{\mathrm{a}}$ Guerra. Essa historiografia de cunho liberal atribuía a um conjunto de causas gerais e externas aos próprios processos de independência a responsabilidade pela ruptura dos laços coloniais.

Os autores mais importantes associados a esta tradição historiográfica são Jacques Godechot (1956) e Robert R. Palmer (1959), em cujos trabalhos ressaltaram a "vocação burguesa" do "mundo Atlântico" na época das revoluções. Para esses autores, no contexto da crise do absolutismo que afetava o mundo europeu e metropolitano levando-o às revoluções, era natural que estas se generalizassem pelas colônias, incluindo aí as colônias inglesas, o que caracterizava a ocorrência de uma revolução "atlântica e burguesa". As idéias iluministas teriam desempenhado aí um papel fundamental fazendo que, quase que de maneira automática, as elites crioulas na Hispano-América as tivessem prontamente adotado como justificativa para a pronta ruptura. $\mathrm{O}$ conceito de revolução também aqui não aparece problematizado, pois pouca atenção era dispensada às características próprias dos processos internos de cada uma das regiões da Hispano-América e nem sequer se analisava como as idéias liberais iluministas foram apropriadas e re-significadas naquele outro ambiente intelectual.

A publicação do livro La Independencia de America Latina ${ }^{7}$ de Pierre Chaunu, no início dos anos 1970, romperá com esta visão ao formular uma análise que privilegia as contradições e complexidades internas da sociedade colonial como fatores importantes para explicar os movimentos de independência. A contraditória situação vivida pela elite crioula é aqui explicitada. Ela é o grupo social dominante na colônia pela sua condição econômica e social, mas ao mesmo tempo está excluída do acesso aos cargos administrativos, políticos e eclesiásticos, monopólio dos espanhóis peninsulares. Além disso, ela teme a maioria de negros, índios e mestiços, criando muitas vezes mecanismos de exclusão política e social, causando grande tensão racial. Chaunu inova também ao destacar o caráter de guerra civil destes movimentos, por envolveram realistas

${ }^{7}$ CHAUNU, Pierre. La Independencia de America Latina. Buenos Aires, Ediciones Nueva Visión, 1973. 
de um lado e patriotas de outro. Sua análise não deixa de valorizar os fatores externos, apontando a revolução liberal de 1820 na Espanha como o fator decisivo para a definitiva ruptura política e institucional com o império espanhol.

É interessante ressaltar que a historiografia produzida nos anos 1960/70, ao colocar em pauta uma nova agenda de investigação sobre as independências, representou uma ruptura importante com o "consenso historiográfico", a que nos referimos anteriormente, e veio a configurar o que se pode chamar de uma "historiografia revisionista". Nesses anos coincidiram muitos fatores políticos, econômicos, sociais e também acadêmicos, nos planos nacional e internacional, que tiveram grande impacto sobre os historiadores latino-americanos, norteamericanos e europeus que pesquisavam os movimentos de independência no mundo ibero-americano. Além do surgimento de uma nova geração de historiadores profissionais que questionava a ausência de rigor com que as fontes primárias haviam sido utilizadas até então, multiplicou-se o número de alunos nas carreiras de ciências sociais como as de História, Antropologia, Sociologia e Ciência Política, aumentando a diversidade das abordagens e a quantidade de teses, artigos, livros e resenhas sobre o tema das independências. O processo de descolonização pós $2^{a}$ Guerra Mundial e o triunfo da Revolução Cubana ajudam ainda a explicar o crescente interesse pela história da América Latina por parte de historiadores estrangeiros, em particular franceses e britânicos. É sabido também que nos Estados Unidos, nos anos 1960, muitos suportes privados e públicos foram destinados às universidades e centros de estudos, criando ou fortalecendo os chamados Latin American Studies.

A nova agenda investigativa que surge nesta época também foi profundamente marcada pelos debates gerados pela teoria da dependência e pelas diversas correntes do marxismo existentes na época. Essas interpretações colocaram na pauta de discussão conceitos como classes sociais, lutas de classe, dependência e, o que mais nos interessa, o conceito de revolução, suscitando questões relevantes para a análise dos processos de independência: houve alguma mudança nas estruturas econômicas e sociais coloniais? O que aconteceu foi uma "verdadeira" revolução ou uma simples reforma marcada pelo signo da continuidade? As massas populares eram simples atores sociais que seguiam passivamente os líderes crioulos insurgentes? O conflito era de classes, entre crioulos - donos

${ }^{8}$ CHUST, Manuel y SERRANO, José Antonio (Eds.), op. cit., p. 12. 
dos meios de produção - e as camadas populares, a favor da independência e contra a opressão espanhola, ou entre realistas e patriotas?

O importante é que, ao chamar a atenção para as contradições internas da sociedade colonial, interpretações como a de Pierre Chaunu abriram caminho para a valorização do caráter de ruptura e de novidade destes movimentos que aparecerá posteriormente nas abordagens historiográficas da década de 1980, e que ultrapassarão em grande medida os estudos marcados até então pela idéia de continuidade. Mas era necessário dar um passo adiante, precisando a natureza e as especificidades dessas mudanças e continuidades. As comemorações dos 200 anos da Revolução Francesa no final da década contribuíram definitivamente para a reavaliação do conceito de revolução, incentivando novos estudos sobre os movimentos de independência na América Hispânica.

François Furet em seu livro Pensando a Revolução Francesa ${ }^{9}$, publicado em 1978, reflete sobre o significado da revolução de 1789 e como ela foi pensada através dos tempos. Sua interpretação examina de forma crítica as correntes que dominaram a análise da revolução ao longo do século XX. Furet opõe-se à tradição de história comemorativa, que remonta a Jules Michelet - cuja interpretação, segundo o autor, vai pouco além da repetição dos argumentos dos próprios participantes da revolução -, e recupera a história conceitual, cujo paradigma se encontra em Aléxis de Tocqueville, que ele considera um dos únicos historiadores a propor uma conceitualização rigorosa da Revolução Francesa, fundada em uma crítica da ideologia revolucionária e daquilo que constitui, em sua opinião, a ilusão da Revolução Francesa sobre si própria. Ele também rompe com as interpretações situadas no horizonte do marxismo, propondo novas vias de compreensão do passado. Para Furet as interpretações marxistas da Revolução são produto "de um encontro confuso entre bolchevismo e jacobinismo", que se alimenta de uma concepção linear do progresso humano e que retoma com força as idéias do advento de um novo tempo e do mito da origem advinda de uma ruptura como constitutivas da própria Revolução, tal como foi vivida por seus atores e veiculada por seus herdeiros ${ }^{10}$.

\footnotetext{
${ }^{9}$ FURET, François. Pensando a Revolução Francesa. Rio de Janeiro: Paz e Terra, 1989.

${ }^{10}$ Sobre as críticas de François Furet às interpretações marxistas da Revolução Francesa ver especialmente o artigo "O catecismo revolucionário" publicado primeiramente em Les Annales, $\mathrm{n}^{\circ}$ 2, março-abril de 1971 e novamente publicado em: FURET, François. Pensando a Revolução Francesa. Rio de Janeiro: Paz e Terra, 1989.
} 
A análise alternativa da Revolução Francesa proposta por Furet enfatiza tanto a importância das rupturas como a das continuidades no desenrolar do processo revolucionário francês. Sob a influência das idéias de Tocqueville o autor recupera o peso da permanência da tradição absolutista na Revolução, mas não deixa de analisar os elementos de ruptura subjacentes à instauração de uma política democrática que passou a ocorrer naquele tempo. A Revolução é pensada ao mesmo tempo como um processo histórico, conjunto de causas e conseqüências, e como acontecimento, uma modalidade de mudança e dinâmica particular de uma ação social coletiva.

A obra de Furet teve profunda influência na formulação da análise de François-Xavier Guerra sobre o conceito de modernidade e as independências da América Hispânica. Guerra procede desta mesma tradição historiográfica inovadora e teve entre seus interlocutores mais próximos, inclusive participando da sua banca de doutoramento ${ }^{11}$, alguns dos estudiosos do tema citados aqui, como Pierre Chaunu e François Furet. Desde cedo compartilharam os pontos de vista que privilegiavam tanto a longa duração na cultura hispânica, quanto a crise da modernidade na Europa e em seus impérios coloniais. Sua percepção do caráter revolucionário das independências hispano-americanas enfatizava também assim o seu duplo caráter: ser um processo e um acontecimento ao mesmo tempo.

Segundo Guerra, a partir de 1808, o mundo hispânico iniciou sua passagem para a modernidade política por um duplo caminho. De um lado a ruptura com o Antigo Regime, provocada pelas sucessivas abdicações reais, permitia experimentar e realizar novas formas de soberania e representação política. O primeiro passo nesse sentido foi dado pela formação, tanto na Espanha como na América, de Juntas de governo locais que invocavam o princípio legal hispânico de que a soberania, na ausência do rei, reverteria para os povos. De outro lado, essa conjuntura de crise abriu um espaço concreto para que novas e inesperadas experiências fossem vivenciadas, permitindo aos homens daquele tempo construir novos conceitos, palavras e projetos como respostas a estes desafios.

No interior desse processo de desintegração do império espanhol, FrançoisXavier Guerra identifica dois cortes cronológicos importantes. O primeiro deles o período entre 1808 e 1810, que ele denomina de ponto de mutação. "El

\footnotetext{
${ }^{11}$ A tese de doutoramento de François-Xavier Guerra, orientada pelo Professor François Chevalier na Universidade de Paris I, Sorbonne, foi publicada em 1985 e trata do contexto revolucionário mexicano no início do século XX. GUERRA, François-Xavier. Le Mexique de l'Ancien Régime a la Révolution. Paris: L'Harmattan-Sorbonne, 1985, 2 vols.
} 
período de que va de los levantamientos peninsulares de la primavera de 1808 a la disolución de la Junta Central en enero de 1810, es sin duda la época clave de las revoluciones hispánicas, tanto en el tránsito hacia la Modernidad, como en la gestación de la Independencia ${ }^{12}$ ".

Esse período é chamado por ele de ponto de mutação ideológica, momento no qual se trava pela primeira vez o duplo debate: sobre a natureza da representação que traz à tona a questão da igualdade política entre Espanha e América dentro do conjunto mais amplo da Monarquia, e sobre a natureza íntima da nação, a partir das novas referências surgidas no próprio contexto de desintegração do Antigo Regime. Nestes debates se inserem os questionamentos fundamentais sobre os conceitos de soberania e de representação. A ruptura estaria na quebra da antiga relação pessoal e recíproca existente entre os súditos e o rei, definida como uma relação binária. Também a concepção de nação como uma grande família se desintegrava a partir do desaparecimento da figura do rei.

Neste sentido se colocam dois problemas: de um lado, qual o direito que tinham as colônias (na visão dos peninsulares) ou qual o privilégio do outro pilar do império (na ótica dos americanos), de constituir suas próprias Juntas de governo; e, de outro, a igualdade de representação destes "membros do império" nos poderes centrais da monarquia, problema no qual se enfrentavam duas visões da monarquia: a dos peninsulares, unitária e desigual, fundada na Modernidade absolutista, e a dos americanos, plural e igualitária, fundada na tradição pactista.

Segundo François-Xavier Guerra, dois novos fenômenos viabilizaram essa mutação ideológica pelo continente americano: a abundante proliferação de publicações que tornava viável o acesso de uma boa parte da população às novas idéias liberais que passaram a circular mais no ambiente colonial hispano-americano; e o surgimento de novas formas de sociabilidade, como as tertúlias e os Clubes Literários, que passavam a constituir importantes espaços nos quais esse pensamento ilustrado era discutido. São esses novos espaços políticos que permitem que os homens daquele tempo compartilhem visões de mundo, sentimentos e projetos, constituindo um novo vocabulário político, capaz de gerar uma modernidade política.

O segundo corte cronológico identificado na obra de Guerra é delimitado pelo ano de 1810, ano em que as revoluções de independência foram desen-

\footnotetext{
${ }^{12}$ GUERRA, op. cit., p. 115.
} 
cadeadas. As vitórias francesas decisivas de 1809 provocaram a dissolução da Junta Central em janeiro de 1810 e a designação de um Conselho de Regência para atuar em seu lugar. A partir daí algumas províncias da Espanha e vários reinos da América recusaram-se a reconhecer o novo governo, questionando a legitimidade do Conselho e o seu direito de falar em nome da Nação Espanhola. A ruptura se dava então a partir destes acontecimentos detonando o processo revolucionário das independências.

A convocação das Cortes Generales y Extraordinárias em Cádiz, buscou responder às preocupações da maioria das províncias da Espanha e de muitas partes do Novo Mundo. O parlamento espanhol tentava assim proporcionar aos autonomistas americanos um meio pacífico para a obtenção do governo local. Mais ainda, os extensos debates naquele congresso, amplamente disseminados pela imprensa no período de 1810 a 1812 , influenciaram significativamente tanto os espanhóis-americanos que apoiaram, como aqueles que se opuseram ao novo governo na Espanha ${ }^{13}$.

Os deputados da Espanha e da América, que promulgaram a Constituição de Cádiz em 1812, transformaram de fato o mundo hispânico. Esta Constituição não foi apenas um documento espanhol, foi igualmente americano - atendendo ao mundo atlântico em sua totalidade. Em verdade, pode-se dizer que, sem a participação dos deputados do Novo Mundo, dificilmente a Carta de 1812 tomaria a forma que tomou. Foram os seus argumentos e propostas que convenceram os espanhóis da necessidade de importantes reformas liberais, como no caso da criação de comissões ou delegações provinciais e da permissão para que cidades com mais de mil habitantes formassem ayuntamientos, transferindo assim o poder do centro para muitas localidades.

A Constituição de 1812 aboliu as instituições senhoriais, a Inquisição, o tributo pago pelas comunidades de índios e o trabalho forçado - como a mita na região andina. Criou um estado unitário com leis iguais para todas as partes da Monarquia Espanhola, restringiu substancialmente a autoridade do rei e confiou às Cortes o poder da decisão final. Ao conferir o direito de voto a todos os homens, com exceção dos de ascendência africana, sem requerer qualificações de renda ou exigir grau de alfabetização, a Constituição de Cádiz superou as

\footnotetext{
${ }^{13}$ Ver as Introduções de MÄDER, Maria Elisa e PAMPLONA, Marco Antonio (Orgs.). Revoluções de independências e nacionalismos nas Américas. Região do Prata e Chile. Vol. 1. São Paulo: Paz e Terra, 2007 e RODRÍGUEZ O., Jaime E. (coord.). Revolución, independencia y las nuevas naciones de América. Madrid: Fundación MAPFRE TAVERA, 2005.
} 
dos demais governos representativos existentes à época - como Grã-Bretanha, Estados Unidos e França - no que se refere à extensão de direitos políticos para a maioria da população adulta masculina.

Em que pese à ampliação sem paralelos da representação política, guerras civis irromperam na América entre aqueles grupos que, insistindo na formação de Juntas locais, se recusavam a aceitar o governo na Espanha, e aqueles outros que reconheciam a autoridade da Regência e das Cortes, mantendo-se fiéis a elas. As divisões políticas entre os membros das elites mesclavam-se às antipatias regionais e tensões sociais, na exacerbação dos conflitos no Novo Mundo. Essa sucessão de eventos criou as condições para vivências definidoras de novos comportamentos e atitudes que, segundo Guerra, gestavam a modernidade política em seu sentido plenamente processual.

É hoje uma hipótese bastante trabalhada a idéia de que a fase crucial da transformação semântica que mudou profundamente as linguagens políticas e sociais no âmbito histórico-cultural do mundo ibérico se abriu com a crise dinástica, bélica e constitucional de 1807-1808, que afetou profundamente a ambas as monarquias ibéricas. Este momento decisivo deu início a um período de instabilidade que se prolongaria durante décadas. Tendo em conta a multiplicidade de ensaios constitucionais em toda a região, a dificuldade de fixar limites e fronteiras entre as unidades políticas nascentes que se atribuíam e disputavam entre si a soberania, o variável balanço, enfim, da transição entre o mundo tradicional e as novas práticas e categorias políticas ao longo do tempo, não é exagero caracterizar este período como um gigantesco laboratório aberto à experimentação política. Por tudo isso pode ser pensado como o do advento da modernidade na era das revoluções liberais e das independências.

Tratou-se aqui de desenvolver uma reflexão historiográfica que, sem pretender esgotar tema tão amplo e complexo, buscou analisar como a historiografia tem interpretado os movimentos de independência na América Hispânica, atribuindo-lhes ou não um caráter revolucionário. A idéia foi fazer um balanço de algumas das mais importantes abordagens historiográficas acerca do tema, em especial a análise empreendida por François-Xavier Guerra, destacando principalmente os diferentes conceitos de revolução e os múltiplos significados a partir dos quais estas são conformadas. É reconhecida a amplitude da influência das teses de Guerra nos inúmeros trabalhos publicados atualmente sobre o tema, mas é necessário também apontar para a existência de outros trabalhos inova- 
dores e divergentes que vêm igualmente pautando os debates contemporâneos a respeito das independências no mundo ibero-americano ${ }^{14}$.

É indiscutível o impacto que a democratização, ocorrida no final dos anos 1980 e princípio dos anos noventa, e as críticas aos postulados da teoria da dependência, aos marxismos e à Escola dos Annales - teorias "estruturalistas" que sem dúvida marcaram as pesquisas históricas da Hispano-América -, tiveram sobre os temas de investigação, não só na historiografia, mas nas ciências sociais em geral. As questões da cidadania e da representação política, o liberalismo das Cortes de Cádiz, o papel dos realistas nas guerras de independência, a história dos grupos subordinados e o estudo da linguagem política, por exemplo, apresentam-se desde então com renovada e ampla força, como temáticas atuais que têm contribuído para o enriquecimento das múltiplas possibilidades históricas que se apresentaram à época e para o questionamento da tese da inevitabilidade das independências e, com ele, o do necessário processo de emancipação da nação.

A proximidade das comemorações dos 200 anos da invasão napoleônica e do início dos movimentos revolucionários de independência na América Hispânica tem incentivado um grande número de estudos sobre estes temas nos últimos anos. Os novos olhares lançados especialmente sobre a relação entre as independências e o conceito de revolução, parecem indicar a insuficiência das interpretações clássicas e a tomada de consciência das novas perguntas que podemos lançar ainda sobre esta época-chave para o mundo ibérico. Sem dúvida deste tempo em diante um conjunto de transformações se mostrou irreversível e modificou o porvir do continente americano radicalmente. Constituiu-se aqui um laboratório político e constitucional no qual, ao longo de várias décadas de convulsões e sobre as ruínas dos antigos impérios ibéricos, foi construído um novo mundo político cuja legitimidade se apoiava em um conjunto de noções (constituição, separação de poderes, representação nacional, opinião pública, soberania popular, etc.) que serviram de suporte para as instituições políticas erguidas em nossas sociedades durante aquele século, com todas as suas vicissitudes e descontinuidades. Um período particularmente rico em alternativas políticas e na constituição de sujeitos atuantes deve, certamente, continuar

\footnotetext{
${ }^{14}$ Ver por exemplo os trabalhos de José Carlos Chiaramonte e os artigos publicados em CHUST, Manuel y SERRANO, José Antonio (Eds.)., 2007, op. cit. e RODRÍGUEZ O., Jaime E. (coord.)., 2005, op. cit.
} 
sendo um tema de debates gerados a partir de questionamentos colocados por um presente sempre pronto a trazer novas indagações ao passado.

\section{Referências Bibliográficas}

ANNINO, A; LEIVA, L. C.; GUERRA, F. X. De los Imperios a las Naciones: Iberoamerica. Zaragoza/Espanha: Ibercaja, 1994.

BETHELL, Leslie Ed. (Org.). História da América Latina. Da Independência até 1870. São Paulo: EDUSP; Imprensa Oficial do Estado; Brasília, DF: Fundação Alexandre Gusmão, Vol. III, 2001.

CHAUNU, Pierre. La Independencia de América Latina. Buenos Aires: Ediciones Nueva Visión, 1973.

CHIARAMONTE, José Carlos. Ciudades, provincias, Estados: Orígenes da la Nación Argentina (1800 - 1846). Buenos Aires: Compañia Editora Espasa Calpe, 1997.

CHUST, Manuel. La cuestión nacional americana en las Cortes de Cádiz. Valencia: Universidad Nacional de Educación a Distancia / Centro Francisco Tomás y Valiente/ UNAM-IIH, 1999.

CHUST, Manuel y SERRANO, José Antonio (Eds.). Debates sobre las independencias iberoamericanas. Madrid; Frankfurt: AHILA/Iberoamericana/Vervuert, 2007.

FURET, François. A Revolução em debate. São Paulo: Edusc, 2001.

FURET, François.. Pensando a Revolução Francesa. Rio de Janeiro: Paz e Terra, 1989.

GODECHOT, Jacques. La Grande nation, l'expansion révolutionnaire de la France dans le monde de 1789 à 1799. Paris: Aubier, 1956.

GOUVÊA, Maria de Fátima. Revolução e Independência: notas sobre o conceito e os processos revolucionários na América espanhola. Estudos Históricos, Rio de Janeiro: Ed. FGV/CPDOC, nº 20, 1997.

GUERRA, François-Xavier. A Nação na América espanhola: a questão das origens. Revista Maracanan. Rio de Janeiro: UERJ, 1999/2000, Ano I, no 1.

GUERRA, François-Xavier. Modernidad y Independencias: ensayos sobre las revoluciones hispanicas. México: Editorial Mapfre; Fondo de Cultura Económica, 1992.

GUSDORF, Georges. As Revoluções da França e da América: a violência e a sabedoria. Rio de Janeiro: Nova Fronteira, 1993.

HALPERIN DONGHI, Túlio. Reforma y disolución de los impérios ibéricos, 17501850. Madrid: Alianza, 1985. 
LYNCH, John. Las Revoluciones Hispanoamericanas, 1808-1826. Barcelona: Ariel, 1989.

LYNCH, John. As origens da Independência da América Espanhola. In: BETHELL, Leslie Ed. (Org.). História da América Latina. Da Independência até 1870. São Paulo: EDUSP; Imprensa Oficial do Estado; Brasília, DF: Fundação Alexandre Gusmão, Vol. III, 2001.

MÄDER, Maria Elisa e PAMPLONA, Marco Antonio (Orgs.). Revoluções de independências e nacionalismos nas Américas. Região do Prata e Chile. São Paulo: Paz e Terra, Vol. 1, 2007.

MÄDER, Maria Elisa e PAMPLONA, Marco Antonio (Orgs.). Revoluções de independências e nacionalismos nas Américas. Nova Espanha. São Paulo: Paz e Terra, Vol. 2, 2008.

MORENO, Mariano. Representación de los hacendados y otros escritos. $1^{\text {a }}$ Ed., Buenos Aires: Emecé, 1998.

Nuevo Mundo Mundos Nuevos, Debates, 2008, [En línea], Puesto en línea el 17 mai 2008. URL: http://nuevomundo.revues.org//index32842.html

OZOUF, Mona. Revolução. In: FURET, François e OZOUF, Mona. Dicionário Crítico da Revolução Francesa. Rio de Janeiro: Nova Fronteira, 1989.

PALMER, R. R. The Age of the Democratic Revolution. Princeton University Press, 1989.

RODRÍGUEZ O., Jaime E. La independencia de la América Española. México: Fondo de Cultura Económica, 1994.

RODRÍGUEZ O., Jaime E. (coord.). Revolución, independencia y las nuevas naciones de América. Madrid: Fundación MAPFRE TAVERA, 2005.

Recebido: março/2008 - Aprovado:setembro/2008 